2018, volume 7, issue 4

Slyozko, T., Kurilo, L., \& Mazina, O. (2018). The unique opportunities of accounting to promote transparency of economic processes. Copernican Journal of Finance \& Accounting, 7(4), 115-125. http://dx.doi.org/10.12775/CJFA.2018.024

\author{
Tetyana Siyozko* \\ Science and Research Institute of Social and Economic Development
}

LYUDMILA KURILO**

National University of Kyiv-Mohyla Academy

Oleksandra Mazina ${ }^{* * *}$

University of the State Fiscal Service of Ukraine

\title{
THE UNIQUE OPPORTUNITIES OF ACCOUNTING TO PROMOTE TRANSPARENCY OF ECONOMIC PROCESSES
}

Keywords: rules of the game, institutions, accounting, information, transparent economic processes.

J E L Classification: D80, M41.

Date of submission: February 26, 2019; date of acceptance: April 14, 2019.

* Contact information: t.slyozko@ukr.net, Science and Research Institute of Social and Economic Development, Golosiïvskiy, 98/2, of. 55, Kyiv, 03040, Ukraine, phone: +38 05027517 29; ORCID ID: https://orcid.org/0000-0002-1256-0692.

** Contact information: lyudmila.kurylo@gmail.com, National University of KyivMohyla Academy, Faculty of Economic Sciences, Department of Marketing and Business Management, Skovorody, 2, Kyiv, 04070, Ukraine, phone: +38 066758 16 87; ORCID ID: https://orcid.org/0000-0002-1254-8271.

${ }^{* * *}$ Contact information: oleksandra.mazina@gmail.com, University of the State Fiscal Service of Ukraine, Faculty of Economic, the Department of Accounting, Universytetska, 31, Irpin, Kyivska obl, 08200, Kyiv, Ukraine, phone: +38 09527518 27; ORCID ID: https://orcid.org/0000-0003-1191-3940. 


\begin{abstract}
The article is devoted an important role the Institute of Accounting in the modern economy. This role is supported by unique institutional and informational opportunities determined by its specific characteristics. On the one hand, accounting is the legislative and normative institution through which the controlling and regulating institutions influence the economic processes occurring at each enterprise. On the other hand, the accounting system creates an information database on the actual economic activity of each enterprise required by users. Such a database is formed due to the fact that accounting is an exclusive registrar of business activities: documentation, inventory, assessment, calculation, accounts, double-entry bookkeeping, balance, reporting. These methods have such a mathematical feature that has made it possible to fully them with the latest information technologies. All of these factors allow accounting to provide transparent accounting information to any users and institutions.
\end{abstract}

\title{
INTRODUCTION
}

There is such a sad fact that different types of managers (analysts, economists, financiers, etc.) are often skeptical of both accountants and accounting from which they take information to calculate certain indicators. And how wrong they are because accounting plays an important and irreplaceable role in the functioning of the economy. This is due to the fact that most of the data describing the current economic activity of enterprises are formed in the accounting system. At the same time, this information allows institutions to regulate economy by setting rules on the specific formats enterprises must provide them information. The rules are formalized in different types of reporting. Moreover, this information is accumulated with the help of rules (techniques and procedures) inherent to accounting only. These rules are now also incorporated into modern digital industry allowing to obtain clear and complete information about the activities of the enterprise any time. This means that accounting, has incorporated the rules for regulation of economy and the rules for creation of information and thus now has such special institutional and informational possibilities as to be an indispensable tool for economy. This paper thus strives to elicit and to argument on this role.

\section{THE RESEARCH METHODOLOGY AND THE COURSE OF THE RESEARCH PROCESS}

The research in theoretical part based on use book publications, papers and reports at scientific conferences, and in practical part of the article the Laws of Ukraine, Regulations, Instruction are used. Different research methods were applied: analysis of scientific literature, analysis of laws and regulations con- 
cerning accounting, made a graphical representation of the data in the form of pictures. The aim of the article is to prove that institutional and informational opportunities of Accounting make it an important tool for achieving transparency of economic processes.

Research context: accounting as an information system and as an institution of the state.

\section{THEORETICAL FRAMEWORK AND THEIR IMPLEMENTATION IN PRACTICE}

Analysis of recent publications shows that some authors research the institutional approach to the development of economy and Accounting: Burns and Scapens (2000), Dacin, Goodstein and Scott (2002), Campbell and Klaes (2005), Haidai (2006), Robalo (2014). Others authors are exploring study the question about the role accounting information has in economy, for example, papers: by Brandas, Megan and Didraga (2015), Marius, Denisa and Florina (2012), Trigo, Belfo and Estebanez (2016), Chapman and Kihn (2009), Papazov and Mihaylova (2015); some authors see a close relationship between the information which Accounting provides and requirements as to its institutions and individual users, for instance Navarro-Garcia and Madrid-Guijarro (2016); Banociova and Pavlikova (2014). However, none of them defines the special role of Accounting which combines in itself institutional and informational capacities, takes a pivotal position in economy and can ensure transparency of its data. Because this area of research has not as yet formed, we will try to lay its first foundation and thus the research.

To develop, modern economy requires such an openness of data, which would allow users to know the results of activity of enterprises and based on which various economic processes can be simulated. It should help analyze which management decisions to take and how these solutions would help to improve. It should also establish transparent communication between the participants to attract investors. It should be noted, that accounting system contain huge amounts of extremely important data not only for managers to make appropriate management decisions, but also to be used for regulation of activity of enterprises by various state and non-state institutions, which set the socalled "rules of the game" or institutes. The notion of the "institute" is defined as limitations (the rules of the) formed by people that contribute to the formation of relationships between individuals. Most of these rules are implemented 
in the economic life of enterprises through accounting, its institutional and informational opportunities which make it a central regulator of economy.

\section{INSTITUTIONAL OPPORTUNITIES OF ACCOUNTING}

The highest institution, which coordinating the activity of economy, is the State. It creates universal principles of conduct for most subjects and implements them through State institutions: The Supreme Council, the Cabinet of Ministers, the National Bank of Ukraine, Ministries and Departments, Oversight bodies, the Police, etc. Societal institutions in addition to state define this order. To mention a few, they are joint stock companies, political parties, nonprofit organizations, educational institutions, etc. All these institutions regulate economy by means of the capacities Accounting as an institute provide. These capacities are embodied in its regulatory framework and are split into several levels (figure 1).

Figure 1. Model of institutional or regulatory-legal support (Regulation) of accounting and reporting

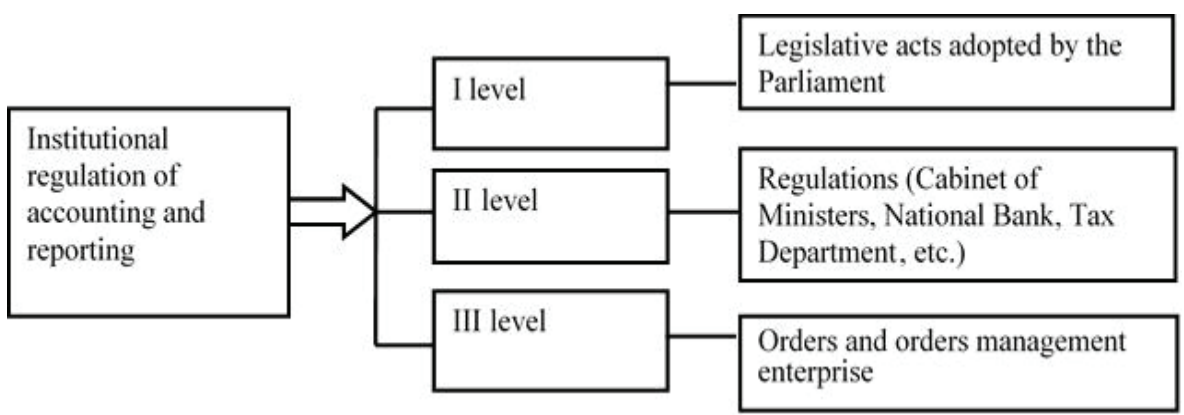

S o u r c e : own elaboration of author.

As can be seen from fig. 1, at the first level (I) there are legislative acts (Laws), adopted by the Supreme Council. At the second (II) level there are normative acts, for example the resolution of the Cabinet of Ministers, the National Bank, the Tax Department, etc. The third level (III) is the level of enterprises, where the regulating function is carried out through orders of company management. At the legislative level there are directly related to Accounting laws: The Law of Ukraine No. 996-XIV (1999) “On Accounting and Financial Report- 
ing in Ukraine" and the Tax code of Ukraine (2010). These regulations defined in the Customs Code, the Budget and the Civil Code of the country. Cash flows are controlled by the National Bank. Its rules and principles are implemented through accounting.

However, in addition to cash, enterprises have a variety of other assets. Possession and movement of these are also regulated by standardized rules, or in other words institutes, which are defined by different ministries and departments. All of these rules are implemented into the economic life also by means of accounting through the appropriate instructions. Alongside the governmental, there are a number of non-governmental institutions, which also set their requirements to information created in accounting system. These are the International Accounting Standards Committee (IASC), the International Federation of Accountants (IFAC), the International Organization of Securities Commissions (IOSCO), the World Federation of Exchanges (WFE). IASC implements international standards of accounting and reporting (further on ISAR) through the interaction with the International Federation of Accountants (IFAC).

The purpose of IFAC is to provide uniformity of ISAR financial reporting which would allow all the ISAR users to access information about the financial shape of potential partners in order to select the best. So, ISAR became a platform for the reduction of accounting differences, of significant deviations in the quantity and quality of information in financial reports as well as for transparency of information internationally. All this indicates that institutional capacities of Accounting are formed by means of its information capacities.

\section{INFORMATIONAL OPPORTUNITIES OF THE ACCOUNTING}

It is through the informational capabilities of accounting that correct application by the entrepreneurs of the "rules of the game" can be checked, which are set by the institutions as a requirement for accounting. Based on these rules, it must provide accounting information compliance with the requirements, which established by institutions (financial, taxation) - in a various types of reports. This is due to the fact that only in the system of accounting is registered and accumulates all the information about the assets and liabilities of the enterprise, business transactions with them every day in the mode of its continuous display in the calendar sequence with the help of special methods. There are eight or alternatively four binaries: 
- (1-2) documentation and inventory,

- (3-4) evaluation and calculation,

- (5-6) accounts and double entry,

- (7-8), balance summarizing and reporting.

All of these methods connect into a single information system of accounting all assets, liabilities of an enterprise, their movement and balances on a certain date. Moreover, without this information existence of a company or enterprise is impossible. Thus, Accounting will always have the important place of a registrar of transactions and objects at an enterprise. For this accounting has not only special methods, but also a set of special procedures.

These are the procedures with the use of which a consistent display of objects and business processes "from of a balance sheet and to a balance sheet» is affected. In general, it is this sequence that is called an accounting procedure or an accounting process. It is a sequential execution of the following procedures: (a) opening of accounts on the ledgers, automatically or manually; (b) registration of transactions or business operations in them using the double entry method; (c) posting of these operations is done on synthetic and analytical accounts between which (d) double-entry control is carried out. Based on the above, we come up to approach the summing up, that is, drafting of a trial balance sheet. Before this or parallel is carried out closing of individual accounts. Thus, accounting procedures end in drafting of a balance sheet and reporting. To launch the process of collection, registration and organization of information, all of these procedures should be organized.

In this set of specific methods and procedures should be distinguished by special methods, on which are based the modern accounting system - these are accounts and double entry on them. These methods historically first appeared in 1494 when they were published in a treatise of Italian monk and mathematician Luke Pachioli. And these are the very methods, invented five hundred years ago, turned out to be so mathematical as to be easily computerized with the help of the newest information technologies, which help modern programs: "SAP", "1C: Enterprise"; "Focus-accountancy", "Intelligence Service", "Sail - Enterprise", "Best Report Plus", "Info-accountant", "IT-Enterprise" etc.

Their technological capabilities allow accounting services of a company to work in the web client mode with the information base on the Internet from any place, with cloud-based technologies (Higgins \& Smith, 2015) which consolidate all the necessary information about counterparts, such as bank accounts, registration codes, etc., as well as the employees of the enterprise, for exam- 
ple their position, salary, passport data. The program can automatically create various forms of tax and accounting reports for users and institutions. Some of these institutions, such as tax authorities where companies are registered, can themselves control these operations. They can independently access computer networks of the enterprises to generate tax reports with the use of standard algorithmic procedures and simultaneously carry out operational control over the economic activity of enterprises.

In addition, equipping the localities where business transactions run directly allows to log these operations in the process of their implementation. If also in this case the legislative institutions introduce rules for all the legal and natural entities to conduct payments in non-cash, this will establish an even better framework and thus give more possibilities to ensure transparency of economic processes. Moreover, that almost all participants of the economy receive wages, pensions and social allowances on the card. And when cards become the only medium for reimbursement, including in the retail trade, public catering establishments and services, then the reduction of cash payments will make information transparent both for the managerial personnel and the correspondent regulatory institutions.

In this case not only the State in the person of tax authorities will be able to periodically get reports of companies and thus control their activities but these reports can be used by any other not only external but also internal recipients. And this is of utmost importance for any manager of the company with an integrated database to be able to quickly filter out the necessary information for management reporting so that to timely make a management decision. However, a counterargument or question arises here: how to deal with the issue of commercial secret of management accounting then?

It should be noted that the idea of eliminating commercial secrets is not new at all. Even the former apologists of this doctrine have long been championing the change. They scream: "Managers, I beseech you to adopt the philosophy of complete openness - to disclose to the market information about all the parameters and criteria which you use internally" (Eccles, Herz, Keegan \& Phillips, 2002). Obviously, such changes are related to the revolution in corporate reporting called value reporting. In essence, it is approximation to the new philosophy of result assessment which is based on integration of the main non-financial parameters with financial. Current financial reporting, for example, no longer satisfies the needs of transnational corporations and thus they require to disclose internal information publicly which destroys the long-established 
rule of commercial secret of managerial accounting. In particular, experts suggest to use the model of value reporting, the key idea of which is to achieve greater transparency by reporting on internal performance. And, even more so, placing information on the Internet leads to its openness and accessibility, that is to the loss of trade secret. This approach was researched by Golov (2007), he singled out 12 models construction of information. In almost each of the models it comes not to delimitation of the boundaries between administrative and financial information but on the contrary to them combination, unification of internal and external reporting.

\section{CONSTRUCTION OF THE MODEL OF GENERATION OF TRANSPARENT ACCOUNTING INFORMATION}

Liquidation of commercial secrets is a new practice, but for accounting it does not make any difficulty. This is due to its of informational capabilities, because all of its methods and procedures are organized in such a way as to always provide transparent information about economic activities of an enterprise. And if here would added institutional capabilities of Accounting and its full computerization, the model would allow generation of transparent information for users and institutions as shown in figure 2 .

This model adds important factors needed to fight shadow economy as it: (a) allows central State institutions to autonomously control business operations of enterprises which were registered with tax authorities, by accessing their computer networks; (b) gives the possibility to objectively estimate the existing financial risks of reporting entities on using IFAC Institute; (c) allows to compare the results of activity of enterprises not just in one area but even in economies of different countries, while providing data for an adequate assessment of its potential and for making of appropriate management decisions; (d) promotes modelling various economic processes as experts can easily overview accounting data to take appropriate management decisions and to improve them; (e) allows to better attract investors as the model shows integrated main non-financial and financial parameters, helps to make communication between the participants transparent; (f) requires the users of the model to acquire fundamental knowledge not only about the algorithms of using it through the Internet, but also knowledge of accounting, which should have all the specialists in the fields of economy, that somehow will be forced to use information of accounting. All this demonstrates the extremely important role of Account- 
ing as a tool indispensable for the economy to function in the contemporary environment.

Figure 2. A model of generation of transparent accounting information

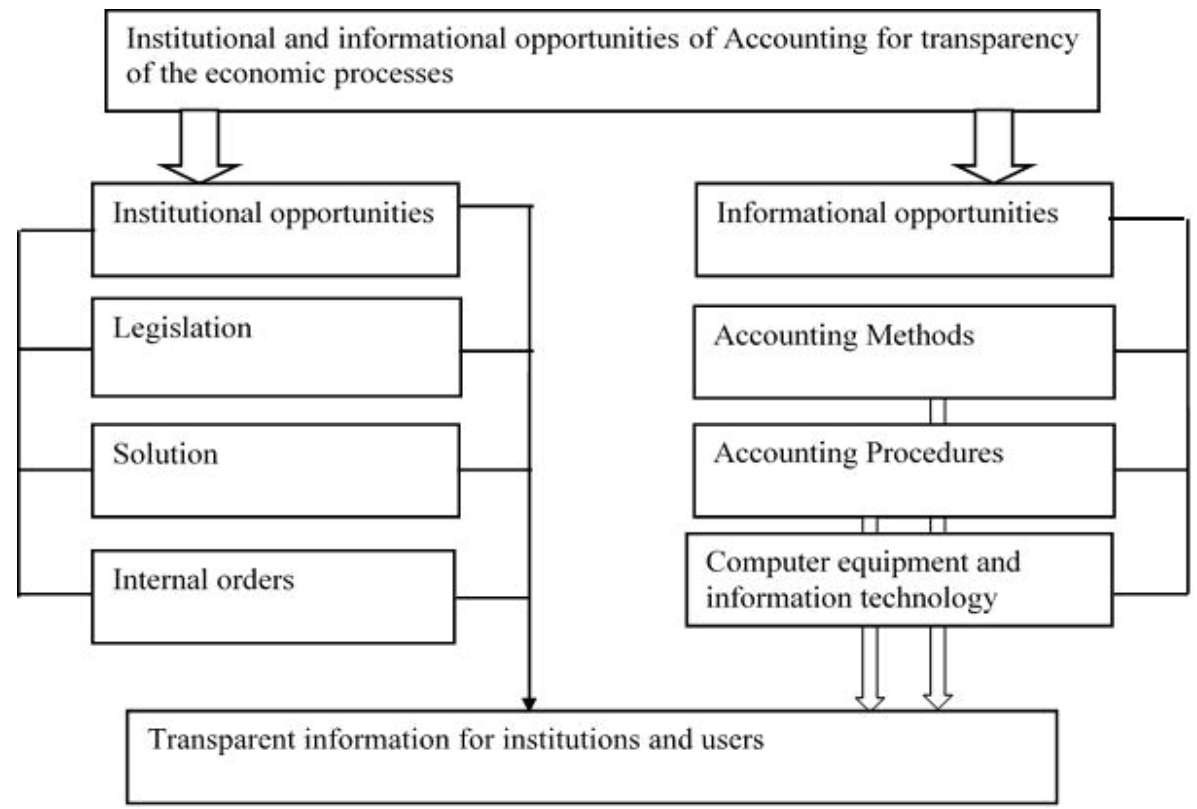

S o u r c e : own elaboration of authors.

\section{CONCLUSIONS}

The research undertaken allowed to demonstrate, firstly, that only Accounting has the unique specifics of combining institutional and informational capacities so that to be an important instrument for regulation of activities both of each individual enterprise and economy in general. It may even be an instrument of regulation of global economy.

Secondly, based on the mentioned examples it was delineated how the institutional capacities of Accounting are realized through legislative and normative acts as entities have to carry out their economic activities within the institutional framework.

Thirdly, informational capacities of Accounting were singled out. These capacities make Accounting the only registrar of business activities through the 
use its techniques and procedures for continuous monitoring, estimation and registration of data about a certain entity in order to for internal and external users to obtain required information.

Fourth, a model was built in which institutional and informational capacities of Accounting due to their computerization and information technologies allow to generate and provide transparent information in order to meet information requirements of institutions and individual users.

Obviously, there are other aspects which help to prepare transparent information for the economy by means of institutional and informational capacities of Accounting. Their identification and justification are only on the initial path of study, and therefore they need further deep research.

\section{REFERENCES}

Banociova, A., \& Pavlikova, L. (2014). Accounting Plan - Information Base for Management. Journal Procedia Economics and Finance, 15, 312-317. http://dx.doi. org/10.1016/S2212-5671(14)00513-9.

Brandas, C., Megan, O., \& Didraga, O. (2015). Global Perspectives on Accounting Information Systems: Mobile and Cloud Approach. Journal Procedia Economics and Finance, 20, 88-93. http://dx.doi.org/10.1016/S2212-5671(15)00051-9.

Burns, J., \& Scapens, R.W. (2000). Conceptualizing management accounting change: an institutional framework. Journal Management Accounting Research, 11(1), 3-25. http:// dx.doi.org/10.1006/mare.1999.0119.

Campbell, D., \& Klaes, M. (2005). The principle of institutional direction: Coase's regulatory critique of intervention. Cambridge Journal of Economics, 29(2), 263-288. http://dx.doi.org/10.1093/cje/bei027.

Chapman, C.S., \& Kihn, L.A. (2009). Information System Integration - Enabling Control and Performance. Journal Accounting, Organizations and Society, 34(2), 151-169. http://dx.doi.org/10.1016/j.aos.2008.07.003.

Dacin, M.T., Goodstein, J., \& Scott, W.R. (2002). Institutional theory and institutional change: Introduction to the special research forum. Journal Academy of Management, 45(1), 45-57.

Eccles, R.J., Herz, R.H., Keegan, E.M., \& Phillips D.M. (2002). The revolution in corporate reporting: How to talk with the capital market on the language value, rather than profit. Moscow: Olimp-Business.

Golov, S.F. (2007). Accounting in Ukraine: An Analysis of the Status and Prospects of Development. Kyiv: Center of educational literature.

Haidai, T.V. (2006). The Institution as an Instrument for Institutional Economic Analysis. Journal Economic Theory, 2, 53-54.

Higgins, J.H., \& Smith B.L. (2015). 10 Steps to a Digital Practice in the Cloud: New Levels of CPA Firm Workflow Efficiency, $2^{\text {nd }}$ Edition. Durham: American Institute of Certified Public Accountants, Inc. http://dx.doi.org/10.1002/9781119449317. 
Marius, C.D., Denisa, C.M., \& Florina, B. (R.) I. (2012). Managerial Accounting - a Source of Information for an Efficient Management in SME. Journal Procedia-Social and Behavioral Sciences, 62(24), 521-525. http://dx.doi.org/10.1016/j.sbspro.2012.09.085.

Navarro-García, J.C., \& Madrid-Guijarro, A. (2016). Real economic activity and accounting information in Spanish construction and real estate firms. Journal Revista de Contabilidad, 19(1), 21-30. http://dx.doi.org/10.1016/j.rcsar.2014.10.002.

Papazov, E., \& Mihaylova, L. (2015). Organization of Management Accounting Information in the Context of Corporate Strategy. Journal Procedia - Social and Behavioral Sciences, 213, 309-313. https//dx.doi.org/10.1016/j.sbspro.2015.11.543.

Robalo, R. (2014). Explanations for the gap between management accounting rules and routines: an institutional approach. Journal Revista de Contabilidad, 17(1), 88-97. http://dx.doi.org/10.1016/j.rcsar.2014.03.002.

The Verkhovna Rada of Ukraine (2010). The tax code of Ukraine. №. № 2755-VI. Available at: http://taxlink.ua/ua/.

Trigo, A., Belfo, F., \& Estébanez, R.P. (2016). Accounting Information Systems: Evolving towards a Business Process Oriented Accounting. Procedia Computer Science, 100, 987-994. http://dx.doi.org/10.1016/j.procs.2016.09.264. 